\title{
The Influence of MUET Score and First Language towards English as a Second (ESL) Learners' Self-Confidence
}

\author{
Zulaikha Khairuddin \\ Academy of Language Studies, Universiti Teknologi MARA, Shah Alam, Malaysia \\ E-mail: zulaikha5497@salam.uitm.edu.my
}

Received: 03-11-2016

Accepted: 15-01-2017

Advance Access Published: March 2017

Published: 01-05-2017

doi:10.7575/aiac.ijalel.v.6n.3p.150

URL: http://dx.doi.org/10.7575/aiac.ijalel.v.6n.3p.150

\begin{abstract}
Speaking skill is an important skill among the four English skills and it is also known as expressive skill. Hence, it is important for students to speak in English confidently and using speaking strategies in order to avoid anxiousness. The two objectives of this study are to identify level of confidence when speaking among Law students and to determine if there is any significant difference in level of confidence when speaking among Law students based on their demographic details (MUET result, first language) respectively. This study employed a purely quantitative study. The instrument used in this study was questionnaire and 380 respondents which consisted of Law students from four local universities in Malaysia) participated in this study The result from this study indicated the level of self-confidence among Law students was above average and it was also portrayed that there was a significant difference in terms of Law students' level of self-confidence based on their MUET result and first language correspondingly. Thus, from the results of the study, it is recommended for the stakeholders which are lecturers, the Faculty of Law, the universities and the policy maker to develop more authentic materials and environment for the students.
\end{abstract}

Keywords: speaking skill, self-confidence, Law student, MUET result, first language

\section{Introduction}

English speaking skills are seen as one of the important skills in helping students for their future employment due to the fact that one of the basic traits that employers search for in fresh graduates is their ability in speaking and communicating in English. In The Star and News Straits Times dated between June to December 2006, there were analysis on the recruitment of employees which found that the most basic skills needed in fresh graduates are oral and written communication skills, interpersonal skills, ability to work in a team, problem solving and decision making skills, leadership and computer literacy (Singh \& Singh, 2008). However, based on a study by Hiew (2012), students) from one of the public universities in Malaysia have low proficiency level in English thought that mastering English carries no benefit for them especially for their future career. English did not have any benefits for them especially for their future career. This situation happens because English is not used as medium of instruction in primary and secondary school that makes them more comfortable to use their mother tongue. Furthermore, English is not the national language of Malaysia (Suliman, 2014).

However, when they want to further their studies, they are required to sit for Malaysia University English Test (MUET) examination (Majlis Peperiksaan Malaysia, 2015). In Malaysia, students had spent between 11 to 13 years of learning English. They studied for six years in primary schools and five to seven years in secondary schools. However, they still could not master English language especially speaking skills (Abdullah \& Abdul Rahman, 2010). This situation is similar with a situation in Hong Kong where the students need to learn English language as their compulsory subject in primary school for six years and secondary school for three years including preparation to enter university for two years (Mak, 2011). However, it is found that Asian students still generally have difficulties in English speaking skills and this includes tertiary level students in Malaysia (Wan Mustapha, Ismail, Singh, \& Elias, 2010).

According to Hiew (2012), there were many factors that contribute to this problem such as students' learning methods, their motivation, perceptions and beliefs. Based on this study, the respondents mentioned that they hesitated to speak in English outside the classroom context because they were terrified of their incorrect use of grammatical structures (Hiew, 2012). They felt embarrassed because their English proficiency levels were low and they received so many negative responses from their friends such as smirks. In other words, they were not confident to use the English language because of their learning environment (Huang \& Hwang, 2013). The study also found that the respondents felt very conscious when they spoke because they thought that others would think of them as not intelligent and incompetent. They also had difficulty in speaking English language because they did not have enough vocabulary and the students are petrified of being evaluated by lecturers and peers of their choice of words (Occhipinti, 2009).

It is possible that this scenario happened because students have high level of anxiety and low self-confidence to speak in English language (Gaibani, 2014). Therefore, primary and secondary school teachers need to address this issue and try 
to resolve it together with the school administration. Apart from that, this issue should also be addressed at the ministry level where the curriculum, is discussed and constituted. There are many studies done on English as a Second Language (ESL) learners' self-confidence (Park \& Lee, 2005; Kubo, 2007, Wu, Yen \& Marek, 2011; Mohammad Al-Hebaish, 2012; Kalanzadeh, Mahnegar, Hassannejad, \& Bakhtiarvand, 2013). However, there is a limited studies which focus on Law students.

\section{Research Questions}

The research questions are:

1. what is the level of confidence when speaking among Law students?

2. is there any significant difference in the level of confidence when speaking among Law students based on their demographic details (MUET result, first language)?

\section{Literature review}

\subsection{Level of Self-Confidence in Speaking English Language and Learners' First Language}

Self-esteem and self-confidence are the important variables for a person to be good in second language acquisition (Park \& Lee, 2005). Level of self-confidence is pivotal for students to be able to speak in English or any second language. Hence, empowering students' confidence level is important because it will affect their language learning (Templin, 1995). According to Templin (1995), the students in Japan have studied the English language for about six years or more. However, they still could not speak in English. They become silent when they are asked to speak or even when they have the opportunity to speak because Japanese students have low level of self-confidence. Other than that, the other factor that makes Japanese students reluctant to speak is because their classroom environment only focuses on written grammar, direct translation, and rote memorization. They focus less on oral communicative competence (Aiga, 1990). In other words, they are not exposed to interactive classroom where both teachers and students need to interact and communicate.Alias and Mohd Hafir (2009) discovered that, students' self-confidence did affect their cognitive perfromace. This study was done towards engineering students who were divided into two groups. One of the groups were given positive stimulus and the other one negative stimulus. It was indicated that positive stimulus' students built their self-confidence better compared to negative stimulus' students.

Students' self-confidence is one of the factors that is highly correlated with students' anxiety level because if the students have high level of confidence, they can manage their anxiety level even when they feel slightly nervous. According to Krashen and Terrell (1983), based on Krashen's Affective Filter Hypothesis (1985), there are a few factors that contribute to students' level of confidence which are students' states self-image, motivations, and emotional state. Low self-confidence can influence the students negatively because they might feel that they are not proficient and have limited vocabulary in the English language. Students who have different levels of confidence will react in different ways when they are asked to attempt a task because different people have different potentials (Park \& Lee, 2005). According to Templin (1995), students needed to have goals that they wanted to achieve whenever they entered the class. At least, they can achieve half of the goals that they had set up. In addition, teachers should also explain to students the objectives of each activity conducted in the teaching and learning process, so that students would try their best to achieve them. It corresponds to Arshad, Zaidi, and Mahmood's (2015) study which indicated that students would perform better in their studies when they are confident towards their capabilities.

Furthermore, the first language interference also affects learners' self-confidence (Archvadze, 2005; Che Musa, Koo, \& Azman, 2012; Derakhshan \& Karimi, 2015). The study done by Che Musa, Koo and Azman (2012) wanted to identify the factors that contributed to low proficiency level of English among Malaysian students. This study was done by using content analysis and thematic analysis. It was found that the first factor of the low proficiency level of English language was because first language interference followed by rote-learning, limited of meaningful learning and pedagogical practice by the educators. Moreover, students have different first languages and they would feel the comfort to speak in their first language compared to the English language (Lekova, 2010) because of first language interference.

Hashemi (2011) reported that students' first language affects their self-confidence to speak the English language. It is because they perceive that they need to use the language with perfect structure. Besides, students' self-confidence would increase when they have positive and pleasant experiences in using English language because they would enjoy and be comfortable to practice the language (Wu, Yen \& Marek, 2011). In other words, exposure is very important in promoting students to use the language. The researchers discovered that English is widely used among Singaporeans, Filipinos and Hong Kongese compared to those who are from Taiwan, Japan and Korea. This may happen because they have, at least, the basics in using English language as they have been exposed to the interaction with native speakers in their countries.

\subsection{Malaysian University English Test (MUET) Score and English Proficiency}

MUET examination is one of the requirements for Malaysian students in order for them to further their study to bachelor degree level and to be accepted to the universities (Majlis Peperiksaan Malaysia. 2015). Based on a study done by Rethinasamy and Chuah (2011), it was found out that there was a relationship between students' MUET score and their performance in English Preparatory class. This means, students who have higher band for MUET score, (Band 4, Band $5 \&$ Band 6) performed better in the preparatory class compared to those who scored lower band for MUET (Band 1, Band 2 \& Band 3). However, students who scored band 3 were discovered to perform better than expected compared 
to Band 1 and Band 2 students. This study was done in one of the public universities consisted of students from all faculties which are 2884 undergraduates.

There are four basic components tested in MUET which are listening, speaking, reading and writing. (Majlis Peperiksaan Malaysia. 2015). For the speaking components, students are being evaluated subjectively even though the examiners are provided with rubrics. There is concern in testing and evaluation field to test communication competence because there is no specific way to evaluate it (Chan \& Wong, 2004). The study indicated that there was a positive feedback from students on MUET Speaking Test. The students said that the test was very helpful in preparing them for their future especially. They felt that the test managed to build their confidence, even though, it was in a short period. Apart from that, students also suggested that MUET should be taught before they sit for the examination. Apart from that, there was a study conducted asking the examiners' perceptions towards students' English proficiency based on their MUET Speaking Test. The examiners stated that there are limitations of MUET Speaking Test such as they might not assessing students' real speaking ability because they need to have prior knowledge on the topic discussed (Sabri, Teah, Balakrishnan, \& Zhang, 2014).

\section{Theoretical Framework}

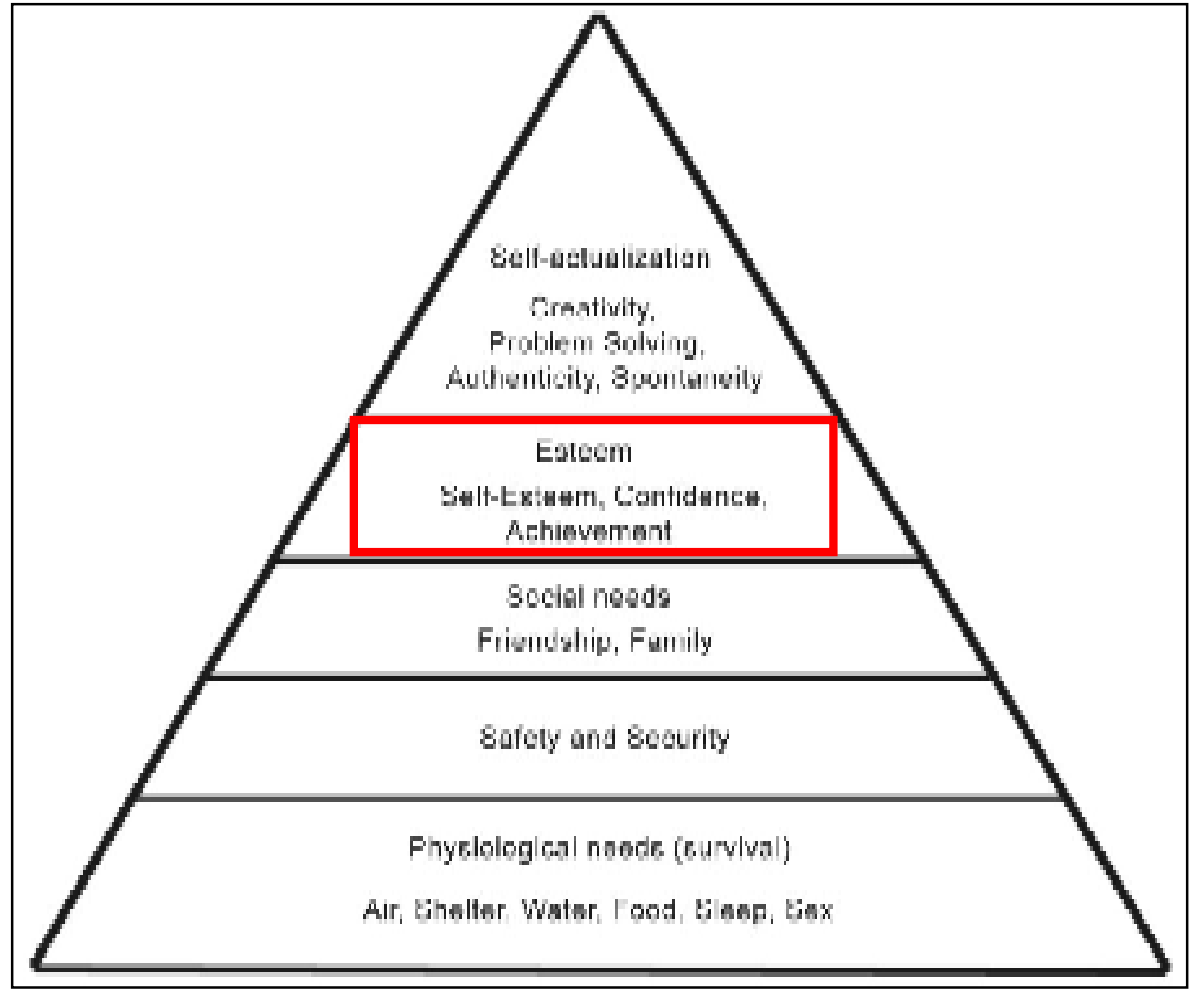

Figure 4.1 Maslow's Hierarchy of Needs

The theoretical frameworks for this study are based on Malosw's Hierarchy of Needs (1943) and Krashen's Affective Filter theory (1985). Based on figure 4.1, the fourth aspect of the hierarchy of needs is esteem needs and the definition of it is the supports that are needed by a person when he or she tries to achieve and accomplish something in his or her lives (Maslow, 1943). Thus, in order to build students' level of self-confidence, the people around them such as parents, family members, teachers and friends need to help them in developing their self-confidence because it would help students directly or indirectly in their future especially when meeting new people and adapting with new environment.

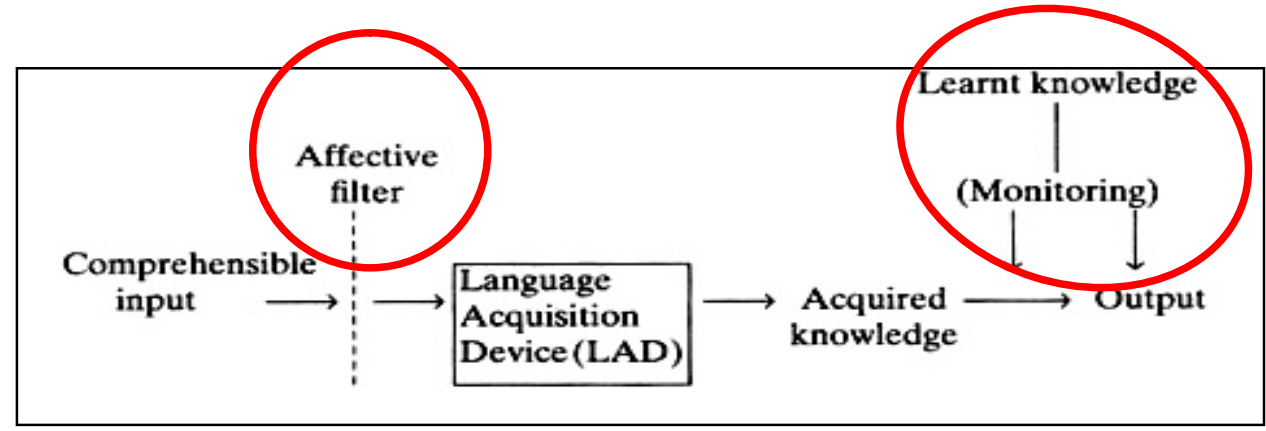

Figure 4.2 Krashen's Affective Filter Hypothesis 
The second theory discussed is on the Krashen's Affective Filter Hypothesis (1985) where Krashen (1985) claimed that the emotional variables in the hypothesis are motivation, self-confidence and anxiety. This hypothesis is also related to the process of students' language learning. In other words, the three variables mentioned would affect students' acquisition in their second language. Lightbown and Spada (2006) interpreted the 'affective filter' as prevention for students in accepting and processing the input from teachers. In other words, students who are not confident of themselves would feel nervous when they receive input and at the same time, it is possible for them to filter out the language input because there are inputs that they could not comprehend. Thus, it can be conceptualised that when the affective filter is high, it means the anxiety level is also high and this indicates that students' self-confidence and motivation is low and vice versa. In short, the two variables do have connection and are inter-related.

\section{Methodology}

The approach of this study was quantitative research by using survey as its research design. The researcher chose to use questionnaire or self-administered survey as the instrument because the researcher tried to obtain information directly from the students about their level of confidence. There were two parts in the questionnaire with 23-items which were:

\section{A: Demographic Details}

a) MUET Score

b) First Language

\section{B: Level of Self-Confidence}

The participants of this study were 400 Law students chosen from four public universities where 100 students were chosen from each university.

This research used purposive sampling because it is more suitable in understanding the phenomenon that this research would like to focus on (Creswell, 2012) when the researcher purposely chose law students. Then, this research employed simple random sampling as the sampling method to ensure that every student who will be selected from each university has equal chance of being selected for the study. In order to collect the data for this study, the researcher went to each university to officially ask permission to conduct the study at the chosen universities and contacted the students' representative for each batch: second year, third year and fourth year students respectively from four universities. Next, the researcher distributed the questionnaires and provided one week for each representative to delegate the questionnaire and collect them back. In order to answer the research questions, the data were analysed using SPSS v20 and presented in the form of means, standard deviations, independent sample $t$ - test, ANOVA and Post Hoc Tests in tables.

\section{Result and Discussions}

6.1 Level of Confidence When Speaking In English among Law Students

Table 6.1 Descriptive Statistics of Level Of Confidence When Speaking in English Among Law Students

\begin{tabular}{lcc}
\hline & Mean & Std. Deviation \\
\hline A students' level of self-confidence & 6.16 & 1.26 \\
D students' level of self-confidence & 6.13 & 1.13 \\
B students' level of self-confidence & 6.10 & 1.26 \\
C students' level of self-confidence & 6.12 & 1.14 \\
Overall Law students' level of self-confidence & 6.13 & 1.19 \\
\hline
\end{tabular}

Table 6.1 shows the descriptive statistics of level of confidence when speaking in English among law students which were computed as 'students' level of self-confidence'. Based on the table, the highest mean score is attained by Law students from A with the mean value $(\mathrm{M}=6.16, \mathrm{SD}=1.26)$ and the lowest mean score is obtained by Law students from $B$ with the mean value $(M=6.10 \mathrm{SD}=1.26)$. The second highest mean value is $(\mathrm{M}=6.13, \mathrm{SD}=1.13)$ which obtained by $\mathrm{D}$ Law students. It is followed with the mean value $(M=6.12, S D=1.14)$ which attained by Law students from $C$. Thus, it can be interpreted that A students' level of self-confidence is the highest because their learning process is held in English language while for other universities the level of self-confidence is similar most probably because they use both languages as their medium of instructions in the classroom, English and Bahasa Malaysia respectively.

This can be concluded that Malaysian Law students had an above average level of self-confidence. This result was in accordance to a study done by $\mathrm{Wu}$, Yen and Marek (2011). In this study it was indicated that students had better level of self-confidence because they were exposed to video-conferencing method. This situation is similar to Law students where they are required to conduct mock trials which is part of their assessment. Apart from that, students were highly likely to assume that they were good in English which was proven by Alias and Mohd Hafir (2009) where students who were given positive reinforcement performed better compared to those who were given negative reinforcement. In other words, students' cognitive performance is important to gain their self-confidence. 


\subsection{MUET Result}

Table 6.2. ANOVA Level of Confidence When Speaking in English among Law Students Based on MUET Result

\begin{tabular}{lccccc}
\hline & SB of Squares & df & Mean Square & F & Sig. \\
\hline Between Groups & 11.893 & 3 & 3.964 & 2.832 & .038 \\
Within Groups & 526.296 & 376 & 1.400 & & \\
Total & 538.189 & 379 & & & \\
\hline
\end{tabular}

The One - Way ANOVA was employed to determine the difference among MUET results attained by Law students from four public universities. Table 6.2 presents the result of One - Way ANOVA test for Law students' selfconfidence according to their MUET results. From this table, it can be seen that the significant difference ( $p=.038$ ) which is $(\mathrm{p}<.05)$. Therefore, Post Hoc test was conducted to see where the difference lies. The result shown in Table 6.2 corresponds to a study done by Arshad, Zaidi, and Mahmood (2015). In their study, it was revealed that students who have better self-confidence would perform better in their academic performance. Hence, it can be seen that students' self-confidence levels significantly influence their MUET results.

Table 6.3 Summary of Post Hoc Tests Multiple Comparisons (MUET)

Level of Confidence When Speaking in English among Law Students Based on MUET Result LSD

\begin{tabular}{lll}
\hline (I) MUET & (J) MUET & Sig. \\
\hline \multirow{2}{*}{ Band 3 } & Band 4 & .069 \\
& Band 5 & .010 \\
Band 4 & Band 6 & .131 \\
& Band 5 & .119 \\
Band 5 & Band 6 & .256 \\
\hline
\end{tabular}

*. The mean difference is significant at the 0.05 level.

Finally, the result of Post Hoc Tests Multiple Comparison is addressed. Table 6.3 reports the result of Post Hoc Tests Multiple Comparison for Law students' self-confidence according to their MUET results. This table shows that the significant $\mathrm{p}$ value between groups Band 3 and Band 4, and Band 3 and Band 6 are $(\mathrm{p}=.069$ and .131) respectively. Furthermore, between Band 4 and Band 5, the significant difference is $(p=.119)$ which is followed by the group between Band 4 and Band 6 with the significant difference $(p=.256)$. Besides, the significant difference between Band 5 and Band 6 is $(\mathrm{p}=.501)$ and finally the significant difference between Band 3 and Band 5 is $(\mathrm{p}=.010)$. From this table, it can be established that the significant $p$ value between Band 3 and Band 4, Band 3 and Band 6, Band 4 and Band 5 and Band 4 and Band 6 as well as Band 5 and Band 6 are $(\mathrm{p}>.05)$. It means there is no statistically significant difference between the groups mentioned above. However, from these tables, it can also be established that the significant $p$ value between Band 3 and Band 5 is $(\mathrm{p}<.05)$.

This means there is statistically significant difference between the groups; Band 3 and Band 5 in terms of students' selfconfidence based on their MUET results. This result was in accordance to Rethinasamy and Chuah (2011) study. In this study, it was indicated that students with different MUET results had different level of English proficiency. This means that students' MUET result did influence their self- confidence in speaking in English language.

6.3 First Language

Table 6.4 ANOVA Level of Confidence When Speaking in English among Law Students Based on Students' First Language

\begin{tabular}{lccccc}
\hline & SB of Squares & df & Mean Square & F & Sig. \\
\hline Between Groups & 14.805 & 3 & 4.935 & 3.545 & .015 \\
Within Groups & 523.385 & 376 & 1.392 & & \\
Total & 538.189 & 379 & & & \\
\hline
\end{tabular}

The One - Way ANOVA was conducted to identify the significant difference among students' first language. Table 6.4 presents the result of One - Way ANOVA test for Law students' self-confidence according to their first language at home. From this table, it can be seen that the significant difference $(\mathrm{p}=.015)$ which is $(\mathrm{p}<.05)$. Therefore, Post Hoc test was conducted to see where the difference lies. The result shown in Table 6.4 is parallel with a study done by Hashemi 
(2011) which mentioned that students' first language did affect their level of self-confidence in speaking English language. It is because they have the perceptions that they need to be able to use the language with perfect structure.

Table 6.5 Summary of Post Hoc Tests Multiple Comparisons (Law Students’ First Language)

Level of Confidence When Speaking in English among Law Students Based on Students' First Language LSD

\begin{tabular}{llc}
\hline (I) First language & (J) First language & Sig. \\
\hline \multirow{3}{*}{ Malay } & Mandarin & .077 \\
& Tamil & .164 \\
Mandarin & Others & .005 \\
Tamil & Tamil & .846 \\
\hline
\end{tabular}

*. The mean difference is significant at the 0.05 level.

Table 6.5 portrays the result of Post Hoc Tests Multiple Comparison for students' speaking anxiety according to their first language at home. These tables illustrate that the significant difference between Malay language and Mandarin language is $(\mathrm{p}=.077)$. Besides, the significant difference for Malay language and Tamil language is $(\mathrm{p}=.164)$. Furthermore, for Mandarin language and Tamil language, Mandarin and Others and Tamil and Others, the significant difference are $(p=.846, .268$ and .489$)$ respectively. Last but not least, the significant difference for Malay language and Others is $(\mathrm{p}=.005)$. From this table, it can be concluded that the significant $\mathrm{p}$ value between Malay language and Others is $(\mathrm{p}<.05)$. It means there is statistically significant difference between the groups mentioned above. It can also be established that the significant difference between Malay language and Mandarin language, Malay language and Tamil language, Mandarin language and Tamil language and Mandarin and Others as well as Tamil and Others are ( $\mathrm{p}>.05)$. This means there is no statistically significant difference between the groups in terms of students' self-confidence based on students' first language at home.This could be related to first language interference (Archvadze, 2005; Che Musa, Koo \& Azman, 2012; Derakhshan \& Karimi, 2015). It was discovered that first language did affect students' level of self-confidence because they felt more comfortable to speak in their mother tongue compared to English language (Lekova, 2010; Che Musa, Koo \& Azman, 2012).

Hence, the conclusion from the result and the discussion, it can be said that students' self-confidence can be improved by using suitable methodology or approach in encouraging them to use the language. Apart from that, students' MUET result did give impact towards their self-confidence because MUET results was ranked from Band 1 which considered as low proficient or poor user of the language and to Band 6 which considered as high proficient or advanced user of the language. Lastly, students' first language did interfere in students' self-confidence because students are most probably felt more confident and comfortable to speak in their mother tongue compared to English language. This is because they might feel that English language was a difficult language to master.

\section{Conclusion}

The result indicated that Law students who participated in the study have an above average level of self-confidence. The study proved that there is a significant difference in the level of self-confidence among Law students based on their MUET results and their first language which reflects that these two elements have impact on students' level of selfconfidence. This is because, MUET result is an indication for students to know the level of their English language proficiency. Hence, there would be a difference from one band to another such as between Band 4 and Band 5. Apart from that, students' mother tongue does play an important role in second language acquisition (Dulay, Burt \& Krashen, 1982). The researchers defined first language interference as direct translation from first language to second language in terms of the grammar and structure.

In order to increase the level of self-confidence, students should know that they have problems to speak in the English language and need to find ways to reduce and overcome the problem. Hence, it is important for Law students to prepare themselves for their future career because in order to be a good lawyer, they must have good speaking and communication skills because as future lawyers, they will have to deal with clients and other lawyers. Apart from that, future lawyers need to know strategies in order to give advices to clients and present and summarise cases in front of the judges. Thus, students have to equip themselves with good speaking skills.

Consequently, if students, as future lawyers, have the ability to speak fluently, accurately and confidently, it will help them to upgrade their credibility and the society at large and legal community will look up upon them. Therefore, it is vital to identify students' level of speaking anxiety and students' level of self-confidence in speaking in English as it can help the stakeholders like students, lecturers, faculties and university's administrators to determine the next step to take to develop and overcome the problem with students' high speaking anxiety level and low level of self-confidence.

\section{References}

Abdullah, K., Rahman, A, \& Lina, N. (2010). A Study On Second Language Speaking Anxiety Among Utm Students. ... Speaking Anxiety Among Utm .... Retrieved From Http://Eprints.Utm.My/10275/

Aiga, Y. (1990). Is Japanese English education changing? Cross Currents, 40,3, 139-146. 
Albalawi, B. R. (2014). Effectiveness of Teaching English Subject using Drama on the Development of Students' Creative Thinking. IOSR Journal of Research \& Method in Education, 4(6), 54-63.

Alias, M., \& Hafir, N. A. H. M. (2009). The relationship between academic self-confidence and cognitive performance among engineering students. Proceedings of the Research in Engineering Education Symposium, Palm Cove, Queensland, Australia.

Archvadze, E. (2005). THe problems of first language interference in the process of teaching sencond language. Tsereteli State University.

Arshad, M., Zaidi , S., \& Mahmood , K. (2015). Self-Esteem \& Academic Performance among University Students. Journal of Education and Practice, 156-162.

Chan, H. S., \& Wong, E. B. (2004). Assessing oral skills of pre-tertiary students: The nature of the communicative act. Proceedings of the International Conference on English Instruction and Assessment, 33-48.

Che Musa, N., Koo , L. Y., \& Azman, H. (2012). Exploring English Language Learning And Teaching In Malaysia. GEMA Online Journal of Language Studies, 35-51.

Creswell, J. W. (2012). Educationa Research: Planning, Conducting and Evaluating Quantitative and Qualitative Research. Boston: Pearson.

Derakhshan, A., \& Karimi, E. (2015). The Interference of First Language and Second Language Acquisition. Theory and Practice in Language Studies, 2112-2117.

Dulay, H. C., Burt, M. K., \& Krashen, S. D. (1982). Language Two. New York: OxfordUniversity Press.

Gaibani, A. A. (2014). Determining the Role of English Language Competence in Influencing the Public Speaking Anxiety of International Post Graduate Students at the University of Utara, Malaysia. International Journal of Learning \& Development, Vol. 4, No. 2, 111-119.

Hashemi, M. (2011). Language Stress And Anxiety Among The English Language Learners. Procedia - Social and Behavioral Sciences, 1811 - 1816.

Hiew, W. (2012). English Language Teaching And Learning Issues In Malaysia: Learners' Perceptions Via Facebook Dialogue Journal. Journal Of Arts, Science \& Commerce, 3(1), 11-19.

Huang, P., \& Hwang, Y. (2013). An Exploration of EFL Learners' Anxiety and E-learning Environments. Journal of Language Teaching and Research , 4(1), 27-35.

Kalanzadeh, G.-A., Mahnegar, F., Hassannejad, E., \& Bakhtiarvand, M. (2013). The Influence of EFL Students' SelfEsteem on Their Speaking Skills. The International Journal of Language Learning and Applied Linguistics World, 7683.

Krashen, S. (1985). The Input Hypothesis. London: Longman.

Krashen, S. D., \& Terrell, T. D. (1983). The Natural Approach: Language Acquisition In The Classroom. Hayward, Ca: Alemany.

Kubo, M. (2007). Examining self-confidence variables: An action research inquiry into pair taping (PT) efficacy. Accents Asia [Online], 1 (3), 42- 62.

Lekova, B. (2010). Language Interference And Methods Of Its Overcoming In Foreign Language Teaching. Trakia Journal of Sciences, 8(3), 320-324.

Lightbown, P. M., Spada, N. (2006). How Language Are Learned. Third Edition, Oxford University Press.

Mak, B. (2011). An Exploration Of Speaking-In-Class Anxiety With Chinese Esl Learners. System, 39(2), $202-214$. Http://Doi.Org/10.1016/J.System.2011.04.002

MajlisPeperiksaan Malaysia (2015). Regulations, Test Specifications, Test Format and Sample Questions. Retrieved from http://portal.mpm.edu.my/documents/10156/5f73205b-9d02-4df9-82ad-ad0da5a05b79. (Accessed on January 7, 2017)

Maslow, A. H. (1943). A Theory Of Human Motivation. Psychological Review, 50(4), 370-96

Mohammad Al-Hebaish, S. (2012). The Correlation betweenGeneralSelf-Confidence and Academic Achievementin the Oral PresentationCourse. Theory and Practice in Language Studies, 60-65.

Occhipinti, A. (2009). Foreign Language Anxiety In In-Class Speaking Activities Acknowledgments, 1-112.

Park, H., \& Lee, A. (2005). L2 Learners' Anxiety, Self-Confidence And Oral Performance. 10th Conference Of PanPacific Association Of .., $\quad$ 197-208. $\quad$ Retrieved From Http://Paaljapan.Org/Resources/Proceedings/Paal10/Pdfs/Hyesook.Pdf

Rethinasamy, S., \& Chuah, M. K. (2011). The Malaysian University English Test (MUET) and its Use for Placement Purposes: A Predictive Validity Study. Electronic Journal of Foreign Language Teaching, 234-245.

Sabri, S., Teah , Q. Y., Balakrishnan, K., \& Zhang, Y. H. (2014). A Review of Speaking Component in SPM and Malaysian University English Test (MUET). The International Journal Of Humanities \& Social Studies, 261-266.

Singh, G. K. G., \& Singh, S. K. G. (2008). Malaysian Graduates Employability Skills. Unitar E-Journal, 4(1), 14-44. 
Suliman, A. (2014). The Interference of Mother Tongue/Native Language in One's English Language Speech Production. International Journal of English and Education, 356-366.

Templin, S. A. (1995). Raise Speaking Self-Confidence. Language teacher-kyoto-jalt, 17(2), 269-274.

van de Pol, J., Volman, M., \& Beishuizen, J. (2010). Scaffolding in teacher-student interaction: A decade of research. Educational Psychology Review, 22, 271-296. http://dx.doi .org/10.1007/s10648-010-9127-6

Wan Mustapha, W. Z., Ismail, N., Singh, D., \& Elias, S. (2010). Esl Students Communication Apprehension And Their Choice Of Communicative Activities. AJTLHE, 2(1), 22 -29.

Wu, W. C. V, Yen, L. L., \& Marek, M. (2011). Using Online Efl Interaction To Increase Confidence, Motivation, And Ability. Educational Technology And Society, 14(3), 118-129. Http://Doi.Org/10.2307/Jeductechsoci.14.3.118 